\title{
Preliminary Studies on Processed Garri as a Source of Bacterial Hazards to Students
}

\author{
Okafor Arthur C. ${ }^{1, *}$, Aquaowo Uwakmfon A. ${ }^{1}$, Ojiagu Kingsley D. ${ }^{2}$, Agu Kingsley C. ${ }^{2}$ \\ ${ }^{1}$ Department of Microbiology, Renaissance University, P.M.B. 01183, Ugbawka, Enugu state, Nigeria \\ ${ }^{2}$ Department of Applied Microbiology and Brewing, Nnamdi Azikiwe University, P.M.B. 5025, Awka, Anambra state, Nigeria
}

Copyright $\bigcirc 2018$ by authors, all rights reserved. Authors agree that this article remains permanently open access under the terms of the Creative Commons Attribution License 4.0 International License

\begin{abstract}
Microbial contamination is considered the most significant hazard associated with food. Data on pathogens present in foods are needed to provide valuable information on the exposure of consumers to certain food borne pathogens. Also, consumption habits among consumers may increase the risk of health hazards. This study aimed to assess some practices, signs and symptoms associated with consumption of soaked garri among university students, to also determine the presence and virulence characteristics of some bacteria in garri on sale in the market. A questionnaire was designed and distributed to a hundred university students to ascertain their perception on safety of garri and handling practices. Fifty samples of garri were randomly collected from the market and assessed for presence of bacteria. Isolates of selected genera were then screened for some virulence-associated properties. The results showed that majority of the students (91\%) affirmed they do consume soaked garri at least once in a while, even though almost $70 \%$ think garri is nutritious. The students (54\%) reported to have experienced at least a symptom of ill health after consuming garri soaked in water. The most commonly reported signs and symptoms were: stomach upset $>$ malaise $>$ fever $>$ nausea $>$ vomitting. There was a direct relationship between the number of students that suspect garri could be a source of illness $(57.1 \%)$ and those that have actually experienced at least a symptom after consuming garri (54\%). Results of bacteriological analysis of garri samples from the market indicated mean total aerobic plate count to be $5.42 \mathrm{log}$ cfu/g. Staphylococcus aureus and Klebsiella were found in $60 \%$ of the samples collected. Most isolates of Staphylococcus aureus, Klebsiella and Pseudomonas were found to be positive for haemolysin and biofilm formation tests which indicate their pathogenic potential. The conclusion is that bacteria with pathogenic potential are common in processed garri being sold in the market and that university students in the habit of consuming soaked garri are probably at risk of health hazards associated with pathogens in garri. Therefore, new food safety regulations should be formulated to incorporate food safety
\end{abstract}

management systems during processing of garri in order to reduce the prevalence of food borne pathogens.

Keywords Garri, Food Safety, Students, Bacteria, Virulence

\section{Introduction}

Garri is the most common cassava-based food consumed in West Africa sub-region. More than $70 \%$ of cassava harvested in Nigeria is processed into garri [1]. It is recognized as a roasted granular hygroscopic starchy food product from cassava (Manihot esculenta crantz). Its processing involves peeling cassava roots, grating the cassava, de-watering and fermenting the mash into a wet cake and roasting the wet material into gelatinized particles. It is then spread on the bare floor or on a mat to allow it to cool before final sieving and packaging for marketing [2, 1]. Also, it is characterized by the following: moderate to high sour taste, white or cream/yellow colour and $0.6-1.1 \mathrm{~mm}$ particle size depending on the method of production and preferences of consumers. Garri has been classified as a "street food" which refers to a wide variety of ready-to-eat foods and beverages sold and sometimes prepared in public places. It is a convenient product because it is stored and marketed in a ready-to-eat form [3]. Hence, it can be consumed directly in the dry form by soaking in cold water, sometimes with sugar, milk and other beverages or processed minimally using boiled water to form stiff paste which is eaten with various types of African soups [2].

However, most garri producers are yet to comply with the garri standards that exist at the level of the Codex Alimentarius Commission. Ogugbue et al., [4] observed that the current method of selling garri in most local markets may pose potential risks to public health. Air-borne contaminants in the market areas were found to 
contribute to the microbial burden of garrri sold in the market. Some bacteria and molds have been reported to be present in garri $[2,5]$, but their pathogenicity is yet to be gauged. Other hazards such as aflatoxins and cyanide have been detected in garri [5, 1]. Also, some studies highlighted the hazards and health problems of local garri processors in Nigeria $[6,7]$. There is yet to be any report focusing on consumers' perception. It has been noted that consumer food safety knowledge and awareness of hazards in foods is vital in meeting food safety goals [8]. Young adults are known to engage in food mishandling practices that keep them at risk for food borne diseases [9].

Most University students are inadvertently exposed to microbial hazards from several sources [10,11], which can cause diseases that go unreported, because their symptoms are mistaken for other ailments such as malaria [8]. Personnel of the Guidance and Counseling unit have expressed concerns that students lose study and lecture periods due to illnesses which turn out to affect their academic performance and emotional wellbeing (Personal communication). The issue is further exacerbated by the fact that most students lack knowledge on the specific food vehicles that transmit common food borne pathogens [12].

The present study aimed at assessing food poisoning-related signs and symptoms, and handling practices associated with consumption of soaked garri among university students. Also, this study targeted at determining the prevalence of bacteria possessing virulence potentials in garri being sold in the market.

\section{Materials and Methods}

\section{Distribution of Questionnaires}

A short questionnaire was designed and distributed to a hundred University students. The questions posed bordered majorly on frequency of consumption, handling practices, food borne disease-associated signs and symptoms resulting from consumption of soaked garri. All the participants provided consent and showed willingness to participate.

\section{Collection of Samples}

Fifty samples of processed garri available for sale in Agbani (a suburb in Enugu state, Nigeria) were randomly collected. The samples were aseptically collected in sterile plastic containers, labeled appropriately and quickly transported to the Microbiology laboratory of Renaissance University for analysis.

\section{Preparation of Samples}

Each sample $(25 \mathrm{~g})$ was homogenized in $225 \mathrm{ml}$ of quarter strength ringers (Oxoid) solution before serial dilution was done. The homogenate was serially diluted up to $10^{-5}$ and aliquot $(0.1 \mathrm{ml})$ of appropriate dilution factor was plated on appropriate media.

\section{Enumeration and Identification of Isolates}

Agar media used include: Tryptose Soy agar, MacConkey agar and Salmonella-Shigella agar. Plates were incubated aerobically at $37^{0} \mathrm{C}$ for 24 hours for enumeration of bacteria.

The bacterial isolates were tentatively identified by morphological properties and biochemical tests such as catalase test, motility test, oxidase test, IMViC test, triple sugar iron test, coagulase test and urea test [13].

\section{Test for Haemolysis}

The blood agar medium was prepared according to the manufacturers' instructions and a loopful of the isolates was streaked on the medium. Plates were incubated aerobically at $37^{\circ} \mathrm{C}$ for 24 hours and examined for zones of haemolysis.

\section{Biofilm Formation Assay}

Brain Heart Infusion (BHI) agar supplemented with $5 \mathrm{~g}$ of sucrose and $0.8 \mathrm{~g}$ of Congo red dye per $100 \mathrm{ml}$ of BHI agar was inoculated with the isolates and incubated at $37^{\circ} \mathrm{C}$ for 24 hours. Black colonies with dry crystalline consistency were positive reaction [14].

\section{Results}

A hundred copies of questionnaire were randomly distributed to 100 university students (40 male and 60 female students; 18-26 years). Ninety-eight students responded: $100.0 \%$ male and $96.6 \%$ female. Majority of the respondents $(91.0 \%)$ affirmed that soaked garri is part of their diet. About $70 \%$ of the respondents think garri is nutritious. The regularity in consumption of garri soaked in water among students is presented in Table 1.

Table 1. Frequency of consumption of soaked garri among university students

\begin{tabular}{|c|c|c|c|}
\hline \multirow{2}{*}{$\begin{array}{l}\text { Frequency of } \\
\text { Consumption }\end{array}$} & \multicolumn{3}{|c|}{ Percent (\%) Affirmative } \\
\hline & Male & Female & Total \\
\hline $\begin{array}{l}\text { Have ever consumed } \\
\text { soaked garri }\end{array}$ & 38.0 & 53.0 & 91.0 \\
\hline $\begin{array}{c}\text { Consume soaked garri } \\
\text { daily }\end{array}$ & 19.4 & 5.0 & 24.4 \\
\hline $\begin{array}{c}\text { Consume soaked garri } \\
\text { weekly }\end{array}$ & 22.4 & 23.5 & 45.9 \\
\hline $\begin{array}{c}\text { Consume soaked garri } \\
\text { monthly }\end{array}$ & 25.5 & 40.0 & 65.5 \\
\hline
\end{tabular}

The choice of materials for storing garri as indicated by the students is summarized in Table 2. 
Table 2. Choice of storage materials for garri among students

\begin{tabular}{cccc}
\hline \multirow{2}{*}{$\begin{array}{c}\text { Choice of storage } \\
\text { materials }\end{array}$} & \multicolumn{3}{c}{ Percent (\%) Affirmative } \\
& Male & Female & Total \\
\hline Polyethylene bag & 30.6 & 41.7 & 72.0 \\
Plastic container & 8.1 & 13.2 & 21.3 \\
Metal container & 2.1 & 4.3 & 6.4 \\
\hline
\end{tabular}

More than half of the respondents (57.1\%) actually suspect garri could be a source of illness. However, $54.0 \%$ of the students reported to have experienced at least a symptom after consuming garri soaked in water (Table 3 ).

Table 3. Signs and symptoms commonly reported among students after consuming soaked garri

\begin{tabular}{cccc}
\hline \multirow{2}{*}{ Signs and symptoms } & \multicolumn{3}{c}{ Percent (\%) Affirmative } \\
& Male & Female & Total \\
\hline Stomach upset & 19.4 & 17.8 & 37.2 \\
Malaise & 16.3 & 17.5 & 33.8 \\
Fever & 14.8 & 17.9 & 32.7 \\
Nausea & 13.2 & 15.3 & 28.5 \\
Vomitting & 14.8 & 9.8 & 24.6 \\
Diarrhoea & 11.2 & 10.1 & 21.3 \\
Blood in stool & 9.1 & 8.2 & 17.3 \\
\hline
\end{tabular}

Moreover, $70 \%$ of the respondents are aware that microorganisms are likely to be present in garri. About $45.9 \%$ and $46.7 \%$ of the respondents know Salmonella and Escherichia coli as food borne pathogens. Some respondents (26.5\%) agree to have some time seen worms in processed garri. Common physical hazards reported among respondents are presented in Table 4.

Table 4. Most common physical hazards in garri as reported among students

\begin{tabular}{cccc}
\hline \multirow{2}{*}{$\begin{array}{c}\text { Common physical } \\
\text { hazards }\end{array}$} & \multicolumn{3}{c}{ Mercent (\%) Affirmative } \\
\hline Sand & 31.6 & 53.0 & 84.6 \\
Hair strands & 18.4 & 37.8 & 56.2 \\
Parts of insects & 17.3 & 25.5 & 42.8 \\
$\begin{array}{c}\text { Pieces of broken } \\
\text { bottles }\end{array}$ & 18.4 & 11.2 & 29.6 \\
$\begin{array}{c}\text { Other physical } \\
\text { hazards }\end{array}$ & 25.5 & 39.7 & 65.2 \\
\hline
\end{tabular}

Generally, $76 \%$ of the respondents affirmed to be in the habit of observing some level of hygienic practices while preparing soaked garri.

After bacteriological analysis of garri samples from the market, mean total aerobic plate count was found to be 5.42 $\log \mathrm{cfu} / \mathrm{g}$. Staphylococcus aureus and Klebsiella were found in $60 \%$ of the samples collected (Table 5), while isolates of selected genera demonstrated some level of virulence associated properties (Table 6).
Table 5. Percentage occurrence of the isolates in the samples

\begin{tabular}{cc}
\hline Probable genera & Percentage (\%) occurrence \\
\hline Salmonella & 26.6 \\
Klebsiella & 60.0 \\
Escherichia coli & 40.0 \\
Pseudomonas & 40.0 \\
Bacillus & 13.3 \\
Staphylococcus & 60.0 \\
\hline
\end{tabular}

Table 6. Percentage of isolates with virulence-associated properties

\begin{tabular}{cccc}
\hline Isolates & $\mathbf{N}^{*}$ & $\begin{array}{c}\text { Percent (\%) } \\
\text { Haemolysin } \\
\text { production }\end{array}$ & $\begin{array}{c}\text { Biofilm } \\
\text { formation }\end{array}$ \\
\hline Klebsiella & 30 & 100 & 82 \\
Escherichia coli & 20 & 100 & NIL \\
$\begin{array}{c}\text { Pseudomonas } \\
\text { Staphylococcus } \\
\text { aureus }\end{array}$ & 20 & 70 & 100 \\
\hline
\end{tabular}

*Number of isolates tested.

\section{Discussion}

The male students appear to consume soaked garri more frequently than the female students considering daily and weekly consumption (Table 1). The data on frequency of garri consumption indicates that soaked garri is prominent in the dietary habit of this group of consumers. This is important for characterizing the risk accompanying exposure to microbiological hazards in foods like garri [15]. Majority of the students (91\%) affirmed that they consume soaked garri at least once in a while, even though almost $70 \%$ of the students think garri is nutritious. This could imply the students consume this food due to its convenience rather than to meet nutritional needs. This lends weight to the general belief that consumption of garri crisscrosses ethnic and socio-economic boundaries [2].

The keeping quality of garri is constrained by its hygroscopic property. Most of the students in this study (72.3\%) prefer storing garri in polyethylene bags (Table 2). Adejumo and Raji [16], found a relationship between packaging materials and the microbial content of garri. Another study concluded that polyethylene bag is suitable for storing garri since it minimized moisture content and microbial load of garri [17]. Thus, the choice of polyethylene bag as garri storage material among the students could be deemed appropriate even though such choice could be based on convenience and ease of conveying the product.

The most commonly reported signs and symptoms that accompany consumption of soaked garri among students were: Stomach upset $>$ Malaise $>$ Fever $>$ Nausea $>$ vomitting (Table 3). These symptoms prominently characterize food borne illnesses [18]. The direct relationship observed between the number of students that 
suspect garri could be a source of illness (57.1\%) and those that have actually experienced at least a symptom after consuming garri (54\%) suggests that their awareness of the risk associated with this food is based mainly on their experience of symptoms rather than food safety education. This is consistent with the fact that the need to improve food safety behavior is often difficult to convey to consumers that have never become ill from poor food safety practices [19].

Also, the students reported the presence of physical hazards in garri (Table 4). These physical hazards probably provide some level of indices for assessing the safety of processed garri since its production and handling methods are yet to be standardized. For instance, Mpuchane et al., [20] analysed body parts and faecal pellets of domestic cockroaches and found a wide spectrum of pathogenic bacteria such as Salmonella, Shigella, Staphylococcus and E. coli. Therefore, that $42.8 \%$ of the students, in the present study, affirmed to have seen parts of insects raises concern on the quality and safety of garri being consumed by these students.

The mean total aerobic plate count obtained from most garri samples in this study was $5.42 \mathrm{log} \mathrm{cfu} / \mathrm{g}$, which exceeds the recommended maximum acceptable limit (3.0 $\log \mathrm{cfu} / \mathrm{g}$ ) for dried food products [4]. However, Ijabadeniyi [21] reported low count of microorganisms in garri at Akure metropolis, Nigeria and concluded that such low count is not enough to establish any health risk.

Staphylococcus aureus and Klebsiella were most frequently isolated from samples followed by Pseudomonas and E. coli (Table 5) which corroborates with the results of another study [2]. Interestingly, these bacteria have been reported in another study to be among the air-borne contaminants in the market areas that contribute considerably to the microbial burden of garri sold in such markets [4]. Klebsiella and E. coli are coliforms which probably indicate the presence of enteropathogens such as Salmonella which was also isolated in the present study. Also, some strains of E. coli, Staphylococcus aureus and Bacillus are enteropathogens. The presence of coliforms in foods is associated with symptoms such as nausea, vomiting, stomach upset and diarrhea [22]. In as much as Pseudomonas species are currently considered as serious food spoilers threatening the quality of food [23], they are likely to serve as reservoirs of some plasmids which confer virulence traits that can be transferred to bacterial pathogens thereby enhancing the pathogenicity of these bacteria.

Haemolysis test as well as biofilm formation assay are some of the phenotypic tests used for initial screening of bacteria for virulent properties $[24,25]$. From Table 6, most isolates of Staphylococcus aureus, Klebsiella and Pseudomonas were found to be positive for haemolysin and biofilm formation tests which indicate their pathogenic potential.

\section{Conclusions}

Most bacteria isolated in this study possessed virulence properties associated with human health threat. Since preparation of soaked garri does not involve any heating process, students in the habit of consuming soaked garri are exposed to bacterial pathogens. There is need to incorporate food safety management systems during processing of garri in order to reduce the prevalence of food borne pathogens.

\section{REFERENCES}

[1] Adebayo, B.A., Nanam, T.D., Bamidele, E.A., and Braima, D.J. (2012). Quality management manual for the production of garri. International Institute of Tropical Agriculture (IITA), Ibadan, Nigeria. 1-41.

[2] Ogiehor, I.S., Ikenebomeh, M.J., and Ekundayo, A.O. (2007). The bioload and aflatoxin content of market garri from some selected states in southern Nigeria: public health significance. African Health Sciences. 7: 233-227.

[3] Mensah, P., Yeboah-Manu, D., Owusu-Darko, K., and Ablordey, A. (2002). Street foods in Accra, Ghana: how safe are they? Bulletin of the World Health Organisation. 80 (7).

[4] Ogugbue, C.J., Mbakwem-Aniebo, C., and Akubuenyi, F. (2011). Assessment of microbial air contamination of post processed garri on sale in markets. African Journal of Food Sciences. 5: 503-512.

[5] Jonathan, S.G., Abdul-Lateef, M.B., and Ayansina, A.D.V. (2013). Fungal and aflatoxin detection in fresh and stored "garri Ijebu" (locally processed food). Report and Opinion. 5: 13-19.

[6] Bamidele, J.O., Adeomi, A.A., Adeoye, O.A., and Oladele, K.E. (2014). Occupational hazards, health problems and peak expiratory flow rates of local gari processors in a rural community in south-south, Nigeria. Journal of Neuroinfectious Diseases. 5: 144.

[7] Koledoye, G.F., Deji, O.F., Owomb.o., P.T., and Toromade, O.G. (2012). Analysis of occupational and environmental hazards associated with cassava processing in Edo state. Agric and Food Science. 1: 26-32.

[8] Ajayi, A.O., and Salaudeen, T. (2014). Consumer food safety awareness and knowledge in Nigeria. Agricultural Journal. 9:191-198.

[9] Byrd-Bredbenner, C., Abbot, J.M., Wheatley, V., Schaffner, D., Bruhn, C., and Blalock, L. (2008). Risky eating behaviours of young adults: implications for food safety education. Journal of the American Dietetic Association. 108: 549-552.

[10] Okafor, A.C., Igwesi, S.N., David, E.J., Okolo, V.K., and Agu, K. (2016). Presence of bacteria with pathogenic potential among already-used toothbrushes from university students. American Journal of Life Science Researches. 4: 16-20.

[11] Amini, R., Abdulamir, A.S., Jahanshiri, F., Shan, L.C., 
Hematian, A., Amini, Y., Sekawi, Z., and Jalilian, F.A. (2012). Isolation and identification of methicilin-resistant Staphylococcus aureus from students' coins. African Journal of Biotechnology. 11: 11143-11149.

[12] Garayoa, R., Cordoba, M., Garcia-Jalon, I., Sanchez-Villegas, A., and Vitas, A. I. (2005). Relationship between consumer food safety knowledge and reported behavior among students from health sciences in one region of Spain. Journal of Food Protection. 68: 2631-2636.

[13] Holt, J.G., editor-in-chief. (1994). Bergey's Manual of Determinative Bacteriology. $9^{\text {th }}$ edition. Baltimore. The Williams and Wilkins Company.

[14] Freeman, D.J., Falkiner, F.R., and Keane, C.T. (1989). New method for detecting slime production by coagulase negative staphylococci. Journal of Clinical Pathology. 42: 872-874.

[15] FAO/WHO, (2008). Exposure assessment of microbiological hazards in foods: Guidelines. Microbiological Risk Assessment Series No. 7. Rome. 1-92.

[16] Adejumo, B.A., and Raji, A.O. (2012). Microbiological safety and sensory attributes of garri in selected packaging materials. Natural and Applied Sciences. 3:153-162.

[17] Ogugbue, C.J., and Obi, G. (2011). Bioburden of garri stored in different packaging materials under tropical market conditions. Middle East Journal of Scientific Research. 7: 741-145.

[18] WHO. (2008). Foodborne disease outbreaks: guidelines for investigation and control.

[19] Woteki, C.E., Facinoli, S.L., and Schor, D. (2001). Keep food safe: healthful food must be safe as well as nutritious. The Journal of Nutrition. 131: 502-509.

[20] Mpuchane, S., Allotey, J., Matsheka, I., Simpanya, M., Coetzee, S., Jordaan, A., Mrema, N., and Gashe, B.A. (2006). Carriage of microorganisms by domestic cockroaches and implications of food safety. International Journal of Tropical Insect Science. 26:166-175.

[21] Ijabadeniyi, A. O. (2007). Microbiological safety of garri, lafun and ogiri in Akure metropolis, Nigeria. African Journal of Biotechnology. 622: 2633-2635.

[22] WHO. (1993). Contaminated food: a major cause of diarrhea and associated malnutrition among infants and young children. Facts infants feed. 1-4.

[23] Nychas, G.J., Skandamis, P.N., Tassou, C.C., and Koutsoumanis, K.P. (2008). Meat spoilage during distribution. Meat Science. 78: 77-89.

[24] Edberg, S.C., Gallo, P., and Kontnick, C. (1996). Analysis of the virulent characteristics of bacteria isolated from bottled water, cooler and tap water. Microbial Ecology in Health and Disease. 9:67-77.

[25] Hassan, A., Usman, J., Kaleem, F., Omair, M., Khalid, A., and Iqbal, M. (2011). Evaluation of different detection methods of biofilm formation in clinical isolates. Brazilian Journal of Infectious Diseases. 15: 305-311. 